The Alfred Bog Committee is now concerned with fundraising to pay off the loan required to make the purchase, with negotiating protection for the remainder of the Bog, and with developing a management plan. Any assistance in this project would be gratefully received.
FRaNk POPE, Chairman Alfred Bog Committee Ottawa Field-Naturalists' Club Box 3264, Postal Station C Ottawa, Ontario K1Y $4 J 5$ Canada.

\title{
International Institute for Environmental Studies and Disaster Management
}

In an attempt to improve knowledge of our environment, another Institution has been formed in the south Asian subcontinent. Stimulated in 1988 by one of the most devastating floods in recorded history, the Bangladesh Research Bureau organized an International Seminar on Bangladesh Floods: Regional and Global Environmental Perspectives, in Dhaka (Bangladesh) from 4-7 March 1989. Events and deliberations that occurred during this important meeting were guided by 35 eminent scientists and other scholars from 17 Countries, and by 182 participants from Bangladesh.

The International Seminar was inaugurated by the President of the Republic, Hussain Muhammad Ershad. In his address the President stressed the need for regional cooperation amongst the neighbouring countries in order to solve the problems caused by such natural disasters, by saying: 'Only one conclusion has emerged today-that these problems need the cooperation and integrated approach of all the countries of this region. Nowhere is interdependence more vital than [in] the rational use and management of internationally shared rivers. Shared rivers are archetypical examples of cooperation-cooperation on the basis of equity, mutual trust, and respect. The use of water from transnational rivers should not be a zero-sum game where one party's loss is the gain of the other party'.

The President also emphasized and wisely counselled the organizers on the formation of an International Centre for studying such environmental problems, by saying, 'Like all other nations, Bangladesh cannot turn a deaf ear to the cries of planet Earth. As a nation with the endless experience of environmental hazards, we would like to share and participate in activities aimed at reducing and ultimately removing those evils. I am, therefore, pleased to ponder on the creation of an International Institute of Environmental Studies in Dhaka, to continue the quest commenced today with multidisciplinary cells to carry on the research. I urge and hope that all other nations and international organizations will extend the necessary assistance to this global venture'.

After three days of intense and fruitful discussion, the scientists present issued the 'Dhaka Declaration', with deliberation on five main themes:

1) Permanent flood-control and management.

2) Floods: socio-economic and legal aspects.

3) Living with flood: The need for disaster management.
4) Geomorphological processes leading to flood.

5) Anthropogenic perturbations of the environment and the greenhouse effect.

Other edicts were also put forward:

1. Recommends the continuation of scientific and technological studies at both regional and global levels. These studies should be directed towards further assessment and understanding of all aspects of environmental sciences, including geochemical and geomorphological processes, climatic factors, etc.

2. Recommends that studies be conducted for developing and coordinating strategies for permanent flood-control and disaster management. These studies should incorporate channel relief, embankment construction, sediment transportation, monitoring, forecasting, an earlywarning system, and rehabilitation.

3. Recommends the formulation of a legal framework, so that it would be possible to examine and apply international laws governing environmental issues and riparian relations at all levels.

The essence of the Seminar's recommendations among other things stressed the need for continuing research and environmental studies in all their ramifications, and underlined the need for global and regional cooperation for the solution of disasters such as floods, storm surges, and other calamities arising out of anthropogenic perturbations.

To achieve these objectives, and following the suggestions made by the President of the Republic, it was resolved that an International Institute for Environmental Studies and Disaster Management would be established in Dhaka.

The Institute was inaugurated on 18 May 1989, and the Board of Advisers (nominated during the International Seminar in March), made up of 18 foreign and 17 national scientists, approved the research programme at its first meeting (19 and $20 \mathrm{May}$ ). The new Institute is thus already in being.

\section{The International Mussel Watch - A Prospectus}

For the past decade, marine environmental scientists have been haunted by the possibility that usages of chlorinated hydrocarbon pesticides in the southern hemisphere and tropics may have increased to the extent that ecosystem damage, similar to that observed in the 1960 s and $1970 \mathrm{~s}$ in the northern hemisphere, may occur also far south of the Equator. This mood has developed on the bases of limited measurements of pesticides in ocean airs and waters as well as some published use and production data.
Further, the UNEP-WHO-Swedish National Food Study on human exposure to selected organochlorine chemicals through the amounts that have been found in human milk, indicated that populations of developing nations such as China, India, and Mexico, possessed the highest values. On the other hand, countries that have prohibited or severely restricted the usages of these biocides had mothers with almost an order of magnitude lower concentrations in their milk. 
In addition there may be a substantial buildup, in southern hemisphere and tropical environments, of such industrial chemicals as polychlorinated biphenyls - through employment of electrical components in which they are used as 'potting fluids'. These compounds have similar effects upon marine organisms to those of the chlorinated hydrocarbon pesticides. Recent spills, especially on the African continent, prompted marine scientists to ask whether or not their levels were attaining values that might jeopardize marine life.

An International Mussel Watch Committee has been formed to evaluate the seriousness of the buildup of levels of chlorinated organic compounds in coastal waters throughout the southern hemisphere and tropics, and to determine whether the levels are such as might threaten marine organisms. The approach will be through measurements of these polluting substances in 'sentinel' organisms, primarily oysters and mussels. Comparison of the results with those from the northern hemisphere of the 1960 s and 1970 s will provide a basis to consider whether or not organisms in the susceptible upper trophic levels are at risk of intoxication from these compounds.

The International Mussel Watch proposal has been formulated to send four teams of collectors to obtain about one thousand samples from about 100 countries in collaboration with local scientists. The samples will receive initial treatment in the field and then be divided for (1) shipment to three regional laboratories for analysis, (2) transfer to local participating laboratories; and (3) processing for archival samples. It is intended to carry out the programme over a three-years' period. The substances to be analysed include the polychlorinated biphenyls and the following chlorinated pesticides: Aldrin, Chlordane, DDT and its degradation products, Kelthane, Mirex, Dieldrin, Endrin, Heptachlor and Heptachlor epoxide, heptachlorbenzene, Lindane, Trans-nonachlor, Mirex, and Toxaphene.

The total cost of the project is estimated to be US $\$ 2,000,000$ (seed funding has been provided by the United Nations Environmental Programme and UNESCO/IOC). The programme will be carried out in three successive steps, each taking about a year: (1) (a) the establishment of a Secretariat to maintain a communications network and a data centre; (b) the identification of participating laboratories and their scientists in 100 countries for collection of samples; (c) the identification of potential regional analytical centres; (d) the identification of sampling sites, sampling organisms, and sampling methods; (e) the collection of production and use data of pesticides from the participating countries, and (f) the establishment of sampling procedures; (2) the sampling and analysis of the $c .1,000$ samples; and (3) data assessment and publication of results.

A secondary goal of the International Mussel Watch is to provide a framework for monitoring other types of chemical contamination that might jeopardize or limit the use of marine resources especially in susceptible regions of the world's oceans. Such a global network of scientists and laboratories could well provide comparable and reliable data for environmental decision-makers.

EDWARD D. GOLDBERG, Chairman
International Mussel Watch Committee
Scripps Institution of Oceanography
La Jolla
California 92093, US.4.

EDWARD D. GoldBerG, Chairman Scripps Institution of Oceanography: La Jolla California 92093, US.A.

\section{[Continued from page 173]}

BERTNESS, M.D. (1984). Habitat and community modification by an introduced herbivorous snail. Ecology, 65, pp. 370-81, illustr.

Cotton, B.C. (1959). South Australian Mollusca, I: Archaeogastropoda. Government Printer. Adelaide, Australia: illustr. [not available for checking].

EWERS, W.H. (1967). The distribution of Velacumantus australis (Gastropoda: potamididae). Australian Journal of Zoology, 15, pp. 581-91, illustr.

FARLEY, J. (1971). A review of the family Schistosomatidae excluding the genus Schistosoma from mammals. Journal of Helminthology, 45, pp. 289-320.

Goss, O.M. (1940). Platyhelminth and acanthocephalan parasites of local shags. Journal and Proceedings of the Roval Society of Western Australia, 26, pp. 1-13.

Grodhaus, G. \& KEH, B. (1958). The marine dermatitis-producing cercaria of Austrobilharzia variglandis in California (Trematoda: Schistosomatidae). Joumal of Parasitology, 44, pp. 633-8.

Groves, R.H. \& Burdon, J.J. (Eds) (1986). Ecology of Biological Invasions in Australia. Cambridge University Press, Sydney, Australia: 166 pp., illustr.

HoDGKIN, E.P. (1971). Report on Investigations into Populations of Velacumantus australis in the Swan estuary (1969 and 1970). Department of Zoology, University of Western Australia, Nedlands, Australia: 8 pp. (mimeogr.).

JOENJE, W. BAKKER, K. \& VLIJM, L. (Eds) (1987). The ecology of biological invasions. Proceedings of the Koninklijke Nederlandse Akademie van Wetenschappen, C90, pp. 1-80, illustr.

Kendrick, G.W. (1960). The fossil Mollusca of the Peppermint Grove limestone, Swan River district of Western Australia. Western Australian Naturalist, 7. pp. 53-66.
KORNBERG. H. \& WILLIAMSON, M.H. (Eds) (1987). Qllantitative Aspects of the Ecology' of Biological Imasions. The Roval Society, London, England. UK: [not available for checking].

Macdonald, I.A.W., Kruger, F.J. \& Ferrar, A.A. (Eds) (1986). The Ecology and Management of Biological Inrasions in Southern Africa. Oxford University Press. Cape Town. South Africa: [not available for checking].

MoONey, H.A. \& Drake, J.A. (Eds) (1986). Ecology of Biological Invasions of North America and Hawaii. Ecological Studies 58, Springer-Verlag. New York, NY. USA: [not available for checking].

ROHDE, K. (1977). The bird schistosome .Alustrobilhar-ia terrigalensis from the Great Barrier Reef. Australia. Zeitschrift für Parasitenkunde, 52, pp. 39-51, illustr.

Walker, J.C. (1978). Velacumantus australis (Gastropoda: Potamididae and Its Trematode Parasites: Some Aspects of the Host-Parasite Relationship. M.Sc. thesis. University of Sydney, Sydney, Australia: [not available for checking].

Christopher C. Appleton

School of Environmental \& Life Sciences

Murdoch University

Murdoch

Western Australia 6150

Australia;

present address:

Department of Zoology and Entomology

University of Natal

P.O. Box 375

Pietermaritzburg 3200

South Africa. 